\title{
Scarcity of sites suitable for nesting promotes plesiobiosis in ants (Hymenoptera: Formicidae)
}

\author{
Wojciech Czechowski
}

Czechowski, W. 2004: Scarcity of sites suitable for nesting promotes plesiobiosis in ants (Hymenoptera: Formicidae). — Entomol. Fennica 15: 211-218.

Plesiobiosis is a rudimentary form of social symbiosis. It consists of the close proximity of nests of different social insect species. Numerous cases of plesiobiosis between ant species observed in a successional series of rocky habitats in S Finland are listed and the most interesting of them are described in detail. Among all Lasius colonies found within the whole successional series studied, as many as $8.4 \%$ were plesiobiotically associated with other ants. In the two earliest successional stages: the shore meadow and the open rocky outcrop, the proportion was nearly $12 \%$ and $10 \%$ respectively. The finding of numerous plesiobiotically related nests there is discussed in the context of the unique local habitat conditions.

Received 24 November 2003, accepted 13 February 2004

Wojciech Czechowski, Museum and Institute of Zoology PAS, Laboratory of Social and Myrmecophilous Insects, Wilcza St 64, PL-00-679 Warszawa, Poland; E-mail: wcz@miiz.waw.pl

\section{Introduction}

Plesiobiosis [original term introduced by Wheeler (1901)] is the most rudimentary form of social symbiosis. It consists of the close proximity of colonies of different species of social insects whose nests border on one another. Typically, plesiobiotic colonies of two or more species may live under the same stone or in the same tree stump. However, their nests - even if they adjoin each other-remain separate as constructions, and individuals from different colonies do not mix. There is no biotic interdependence between them, and they are potentially hostile to one another. As a rule, the plesiobiotic partners differ from each other morphologically, ecologically and ethologically, and usually they represent systematically distant forms; they typically belong at least to different genera (Wheeler 1926, Wuorenrinne 1958, Hölldobler \& Wilson 1990). Generally, they occupy lower, sub- ordinate levels in the hierarchy of interspecific competition (Vepsäläinen \& Pisarski 1982, Pisarski \& Vepsäläinen 1989). Cases of plesiobiosis are included within the category of the so-called "compound nests" (distinct from "mixed colonies") (Wasmann 1891, Wheeler 1926, Hölldobler \& Wilson 1990); however, plesiobiotically related nests remain as individual units.

Several cases and aspects of plesiobiosis have been described recently (Czechowski \& Rotkiewicz 1997, Czechowski \& Yamauchi 1998, Czechowski \& Czechowska 2000, Czechowski 2003), including rather unusual associations between wood ant (Formica s. str.) species and Formica (Serviformica) fusca L. (Czechowski \& Vepsäläinen 1999a, b, Czechowski 2002). Apart from interesting theoretical implications regarding the evolution of social parasitism in ants [wood ants are temporary social parasites and $F$. fusca their host species; see Czechowski \& Vepsäläinen 


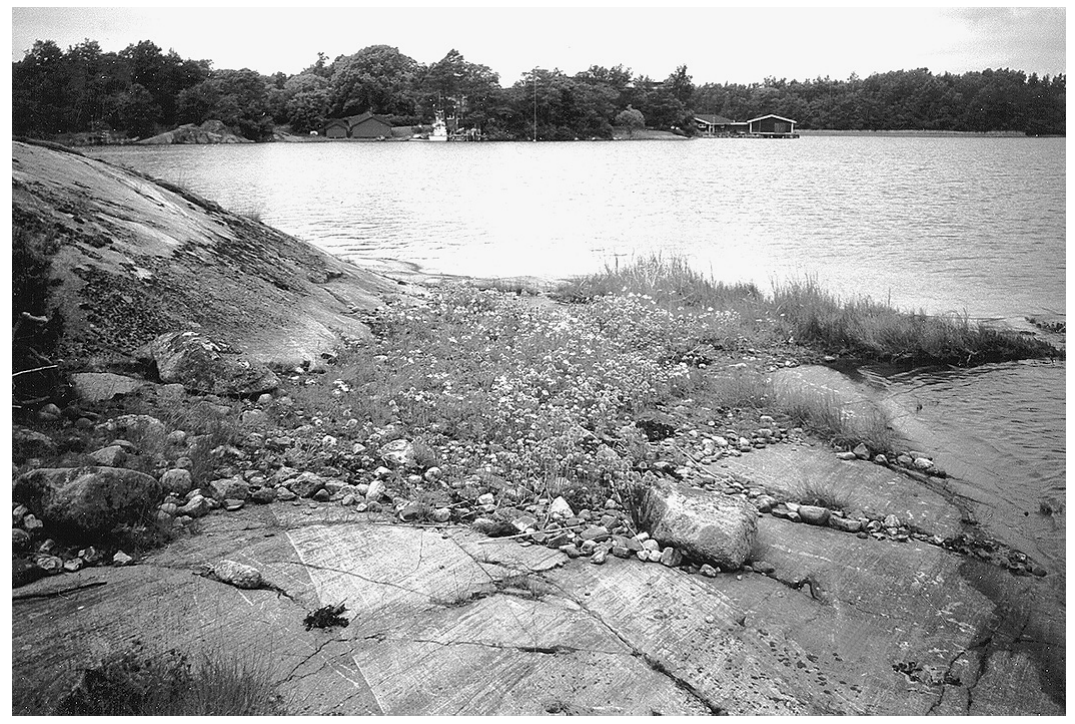

Fig. 1. A shore meadow (island Porsgrundet). (1999a)], many cases of plesiobiosis point to nest competition as causality factor (Czechowski 2002). This in turn provides the basis for a more general hypothesis that plesiobiosis is especially frequent in habitats lacking from sites suitable for the nesting of ants.

Recent investigations on ecological differentiation of sibling species of the subgenus Lasius s. str. that were carried out in Finland by Czechowski, Radchenko, Savolainen and Vepsäläinen (in prep.) were an opportunity to test this hypothesis.

\section{Material and methods}

The study was conducted in the coastal region of southern Finland, on the Tvärminneön peninsula, Hanko, and on several islands of the Tvärminne archipelago, the westernmost part of the Gulf of Finland in the Baltic Sea. The local habitat spectrum consists mainly of different stages of primary succession ranging from the treeless open rocky outcrop to the mature moist pine forest. The rocky outcrop that is the prevailing form is intersected with crevices and interspersed with small patches of vegetation that are sites suitable for ant nesting (Savolainen \& Vepsäläinen 1988, 1989). The myrmecofauna there has been studied by Vepsäläinen \& Pisarski (1982 and unpubl.).

In 2003, nests of Lasius F. species were looked for and registered in the habitats studied. A record was kept of every case of plesiobiosis noticed, not only those involving Lasius ants. Four successional habitat stages (not exactly linear) were distinguished: (1) rocks - an open rocky outcrop with poor herb vegetation in crevices filled with soil; (2) shore meadows - small patches or narrow strips of dense herb vegetation on wave-cut island, usually stony terraces (Fig. 1); (3) forest on rocks a "park-like" sparse pine forest made up of scattered trees (in general, not very old) growing in rock crevices and in vegetation patches that intersperse the rocky outcrop; (4) mature moist foresta relatively thick pine forest with a herb layer growing in depressions with a well-developed soil stratum.

A total of 443 colonies of Lasius were found, including 273 colonies of Lasius s. str. sibling species, L. niger (L.) and L. platythorax Seifert, and 170 colonies of $L$. (Cautolasius) flavus F.

\section{Results}

A total of 29 cases of plesiobiosis (i.e. such a number of couples or triplets of nests) was found: 26 of them were in habitats of the successional series studied (including 23 cases involving Lasius species) and another three were found on the verge of the road along the Tvärminneön peninsula. The most common pair of species was L. (Lasius) 
Table 1. List of the cases of plesiobiosis registered within the successional seria of the rocky habitats (nrs. 1-26) and out of it (nrs. 27-29).

\begin{tabular}{|c|c|c|c|c|}
\hline $\mathrm{Nr}$. & Species & Locality & Habitat & Location of nest, or nest type \\
\hline 1 & L. niger/L. flavus & Kvarnskärgrunden & Rocky outcrop & In rock crevice \\
\hline 2 & L. niger/L. flavus & Kvarnskärgrunden & Shore meadow & Under stone \\
\hline 3 & L. niger/L. flavus & Kvarnskärgrunden & Shore meadow & Under stone \\
\hline 4 & L. niger/L. flavus & Kvarnskärgrunden & Shore meadow & Under stone \\
\hline 5 & L. niger/L. flavus & Allgrundet & Shore meadow & In soil at rock \\
\hline 6 & L. niger/L. flavus & Allgrundet & Shore meadow & Under stone \\
\hline 7 & L. niger/L. flavus & Allgrundet & Shore meadow & Under stone \\
\hline 8 & L. niger/L. flavus & Vikaskär & Shore meadow & Under stone \\
\hline 9 & L. niger/L. flavus & Vikaskär & Shore meadow & Under stone \\
\hline 10 & L. niger/L. flavus & Vikaskär & Shore meadow & Under stone \\
\hline 11 & L. flavus/F. fusca/M. rubra & Tvärminneön & Forest on rocks & Under wood \\
\hline 12 & L. platythorax/L. flavus & Tvärminneön & Forest on rocks & Overgrown soil mound \\
\hline 13 & L. platythorax/L. flavus & Tvärminneön & Forest on rocks & In rock crevice \\
\hline 14 & L. flavus/F. fusca & Tvärminneön & Forest on rocks & In rock crevice \\
\hline 15 & L. flavus/F. aquilonia & Tvärminneön & Forest on rocks & F. aquilonia mound \\
\hline 16 & L. flavus/F. fusca & Tvärminneön & Forest on rocks & Overgrown soil mound \\
\hline 17 & L. niger/L. flavus & Kvarnskär & Shore meadow & Under stone \\
\hline 18 & L. niger/M. rubra & Porsgrundet & Shore meadow & Under stone \\
\hline 19 & L. platythorax/M. rubra & Porsgrundet & Forest & In rotten wood \\
\hline 20 & L. niger/L. flavus & Munken & Shore meadow & Under stone \\
\hline 21 & L. platythorax/L. flavus & Joskär & Rocky outcrop & Under stone \\
\hline 22 & L. platythorax/F. fusca & Tvärminneön & Forest on rocks & In rotten wood \\
\hline 23 & L. flavus/F. fusca & Tvärminneön & Forest on rocks & Under stone \\
\hline 24 & M. rubra/L. muscorum & Porsgrundet & Shore meadow & Under stone \\
\hline 25 & F. truncorum/F. fusca & Tvärminneön & Forest on rocks & In rock crevice \\
\hline \multirow[t]{2}{*}{26} & F. lugubris/F. fuscal & & & \\
\hline & L. acervorum & Tvärminneön & Forest on rocks & F. lugubris mound \\
\hline 27 & L. niger/M. rubra & Tvärminneön & At road & Between asphalt edge and grass \\
\hline 28 & L. flavus/T. caespitum & Tvärminneön & At road & Under stone \\
\hline 29 & L. platythorax/F. fusca & Tvärminneön & Forest clearing & In and at rotten trunk \\
\hline
\end{tabular}

niger/L. (Cautolasius) flavus. For these, and other plesiobiotic associations, see Table 1.

Among all 443 Lasius colonies registered within the whole successional habitat series, 37 colonies $(8.4 \%)$ were plesiobiotically associated with other ants. Most frequently, their partners were colonies of other Lasius species (always, however, of a different subgenus). L. flavus appeared to show greatest disposition to plesiobiotic relations, with $11.2 \%$ of its colonies living in plesiobiosis with another species. In L. niger that proportion was $7.1 \%$, and in L. platythorax $5.6 \%$.

The shore meadows were the habitat type most conducive to plesiobiotic relations. As many as $11.8 \%$ of all Lasius colonies registered there (22 out of 186) were plesiobiotically related to other colonies, compared to $9.8 \%$ in the open rocky out- crop (4 out of 41), and 5\% (10 out of 200) in the forests on rocks. The only case of plesiobiosis in the latter seemed to be accidental and the ant association short-lived. The co-nesting was between an incipient colony of $L$. platythorax (a queen and 4 workers) and a mature colony of $M$. rubra (nr. 19 in Table 1 ). The L. platythorax colony had practically no chance of developing and surviving amidst the extremely abundant $M$. rubra population that occupied this part of the island. Another case of plesiobiosis between L. platythorax and $F$. fusca observed in the forest on rocks (nr. 22 in Table 1) was somewhat similar to the former. Both sides there were represented by incipient colonies.

There is a significant difference between the plesiobiotic/non-plesiobiotic Lasius nest ratios in the first and the one before last successional stages, 

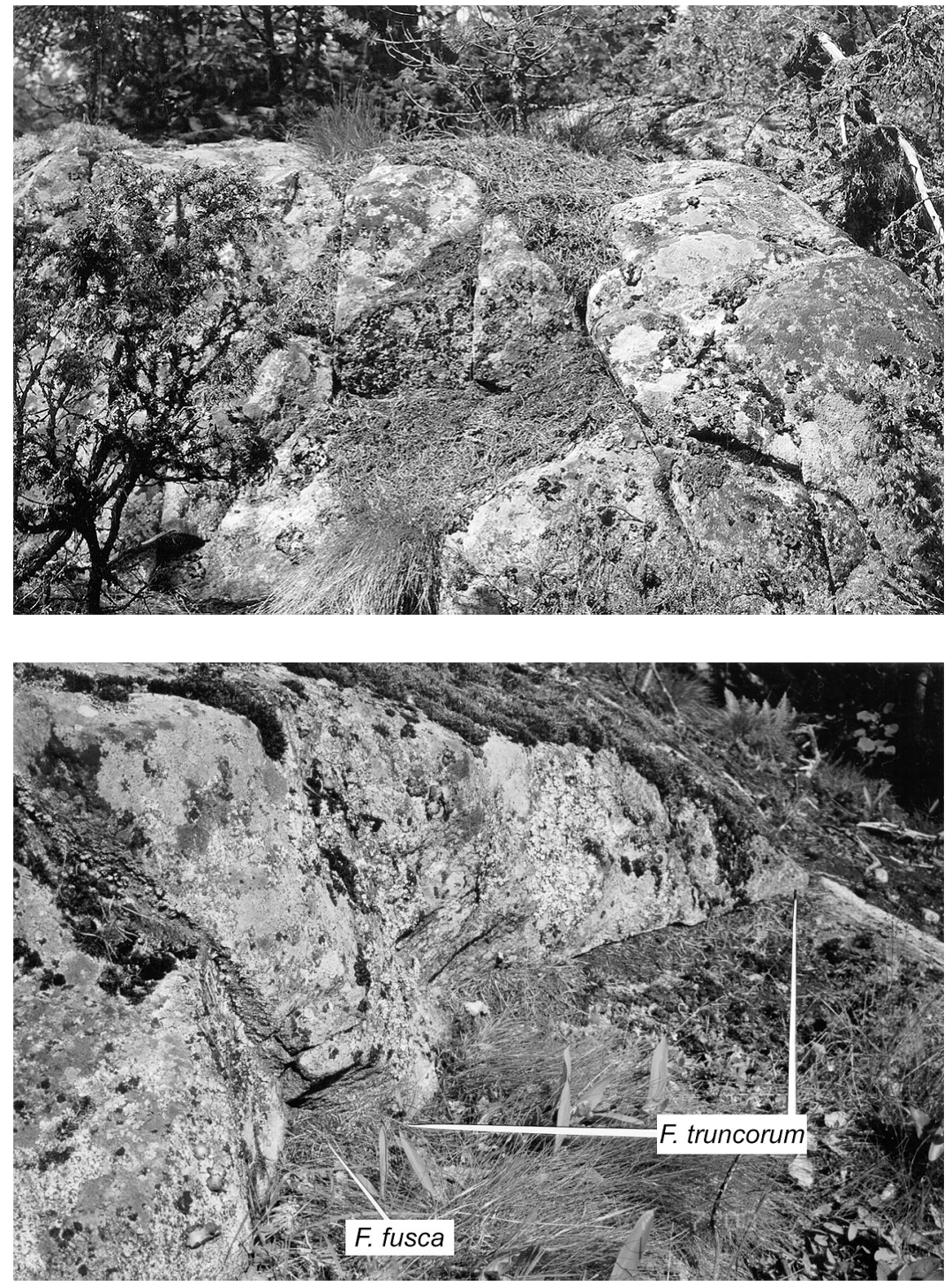

Fig. 2. Plesiobiosis between $F$. aquilonia (the top part of the mound) and $L$. flavus (the lower part of the mound) (the case nr. 15; see Table 1).

Fig. 3. Plesiobiosis between $F$. truncorum and F. fusca (the case nr. 25; see Table 1). i.e. the shore meadow vs. the forest on rocks $\left(\chi^{2}=\right.$ $6.71, \mathrm{p}<0.01)$. Analogous difference between the open rocky outcrop and the forest on rocks is not statistically significant $\left(\chi^{2}=2.45, \mathrm{p}>0.05\right)$. The last successional stage (the mature pine forest) ought to be used for these comparisons, however the material obtained there was too scant and thus might be accidental.

Some particular cases of plesiobiosis (nrs. 12, $14,15,25,26,28$, and 29 in Table 1) are remarkable as regards their form or expression, and due that they may be considered "untypical" ones thus especially interested from the myrmecologi- cal point of view. The first five of them were observed in the successional habitat series under discussion, and the two remaining ones were seen outside that area.

- nr. 12. L. platythorax/L. flavus. A compound nest in a rock crevice, with a soil mound overgrown with moss and grass (typical of $L$. flavus). The centre of the mound was occupied by a colony of Lasius sp., and it was encircled by an L. flavus colony.

- nr. 14. L.flavus/F. fusca. Alinear, 2 meters long L. flavus nest in a rock crevice, interrupted in 
Fig. 4. Plesiobiosis between F. lugubris, F. fusca and $L$. acervorum (the case nr. 26; see Table 1).

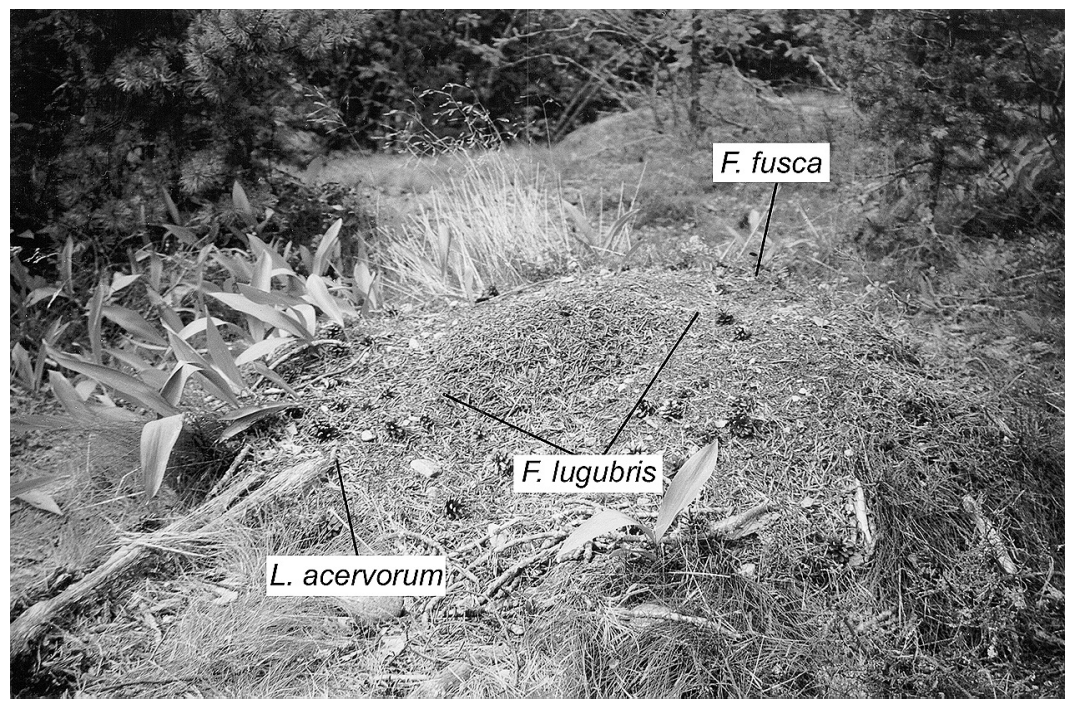

Fig. 5. Plesiobiosis between $F$. fusca and $L$. platythorax (the case $\mathrm{nr}$. 29; see Table 1).

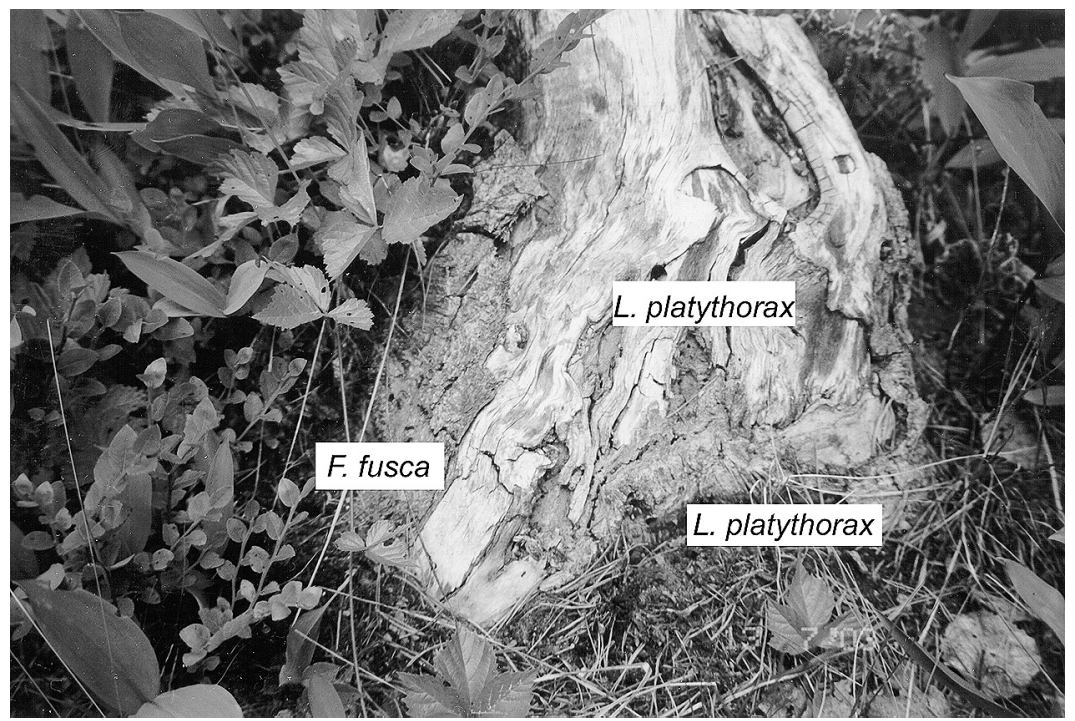

its central part by a nest of $F$. fusca.

- nr. 15. L. flavus/F. aquilonia. Originally a nest of $F$. aquilonia with a two-storeyed mound, situated on the top of the rocks and below, on a small ridge. Both parts of the mound were narrowly interconnected along a vertical rock crevice. In the observation period only the upper part was inhabited by a weak (dying out?) wood ant colony, whereas the lower one was occupied by L. flavus (Fig. 2).

- nr. 25. F. truncorum/F. fusca. Originally a linear, 1.5 meter long nest of $F$. tuncorum in a rock crevice, wholly inhabited by wood ants in the previous season. In 2003, one end of the nest, $25 \mathrm{~cm}$ long, was occupied by F. fusca, whereas the rest was still inhabited by F. truncorum. A route of the latter ants led over the F. fusca part (Fig. 3).

- nr. 26. F. lugubris/F. fusca/L. acervorum. Originally (as recently as the previous year) F. lugubris mound $1.1 \mathrm{~m}$ in diameter. In 2003, the wood ant colony distinctly declined and occupied only the central part of the mound, 40 $\mathrm{cm}$ in diameter, showing, however, great building activity. Colonies of $F$. fusca and $L$. acervorum nested vis-à-vis each other at edges 
of the old mound, 40 and $30 \mathrm{~cm}$ away respectively from the part inhabited by $F$. lugubris (Fig. 4). On 8 July a nuptial flight of $L$. acervorum took place and this aroused no wood ants' interest.

- nr. 28. L. flavus/T. caespitum. A compound nest under a stone contained in an abandoned nest (a mound) of Formica exsecta NYL. at the road. During the previous season the nest was fully inhabited by $F$. exsecta.

- nr. 29. L. platythorax/F. fusca. A tree trunk in a grassy forest clearing with a nest of $L$. platy thorax partly inside the trunk and partly at its foot, and a nest of $F$. fusca at the trunk foot. The compound nest was noticed on 11 July 2003, and on that day single F. fusca workers managed to get inside the trunk. They obstinately looked into holes and crevices, from time to time pulling out a $L$. platythorax worker. The victims were killed and carried to the F. fusca nest. This situation lasted till 13 July, when L. platythorax ants started to transfer their pupae from inside the trunk to the underground part of the nest (Fig. 5).

\section{Discussion}

Within the whole successional series of the rocky habitat studied in Finland, every twelfth colony of the genus Lasius was plesiobiotically associated with another ant colony. In the earliest successional stages of this series, i.e. on the shore meadows and the open rocky outcrop, the respective proportions were as high as one out of every eight and one out of every ten such Lasius colonies. While there are no proper quantitative data from (lowland) Central-European habitats, the author's own observations in Poland appear to indicate that plesiobiotic ant nests are much more difficult to find there. On the other hand, the data under discussion may be compared with very similar observations obtained in quite different habitat conditions in S Finland, namely in a sand dune complex with pine forest near the village of Tvärminne. About 30 ant species cohabit this dune complex (Gallé 1991; see also Czechowski 1999, 2000, 2001, Czechowski \& Vepsäläinen 2001), with nest densities in various successional stages ranging from 2.0 to 37.4 per $100 \mathrm{~m}^{2}$ (Gallé 1991).
In 2001, the occurrence of Lasius s. str. species was investigated in a series of successional habitats, from sand surfaces with very sparse grass or sedge cover to pine forest (Gallé 1991). A total of 112 nests of Lasius s.str. (L. psammophilus Seifert, L. niger and L. platythorax) were registered (Czechowski, Czechowska \& Vepsäläinen in prep.). No case of plesiobiosis involving these species was revealed, and only one pair of plesiobiotic nests of other ants (F. fusca/M. rubra; Czechowski 2003) was seen in the course of that study. Each of the dune successional stages represented a habitat incomparably more homogeneous than rocky habitats are, and each of the former offered ants incomparably larger area suitable for nesting than the latter do.

Therefore, the scarcity of sites suitable for nesting may be suspected as a factor conducive to plesiobiotic relations (or rather forcing their formation) in ants that inhabit rocky habitats. The lack of sites was obvious in the open rock outcrop and also the forest on the rocks. Soil-dwelling ants can only nest there in rock crevices filled with earth, and the total surface of such microhabitats is very small, compared to the entire area. Despite apparent differences, the same applies perhaps even to a greater extent to the shore meadows. In this habitat, ants appear to nest almost exclusively under stones, and only in places that are not too moist (i.e. relatively far from the shore) and with a sufficiently thick layer of soil on the rock. On the other hand, the shore meadows are very attractive for ants, as they can be considered a habitat rich in food resources, especially in comparison with the adjacent open rocky areas. In the former, apart from the local soil, epigean and epiphytic invertebrates, and honey-dew, staple food of ants, there are shore silts that are also rich in protein particles. The combination of these two habitat factors, a lack of nesting sites on the one hand, abundant food on the other, necessarily makes interspecific competition in ants especially intense. Plesiobiosis appears to be a way out of this situation, the phenomenon itself being possible due to differences in species' biologies and their positions in the competitive hierarchy.

Some particular cases of plesiobiosis are after all amazing in the light of earlier results. For example, $L$. niger and $M$. rubra actually compete with each other for food and nesting sites when 
they live in seemingly optimum habitats (Czechowski 1985).

Finally, it is noteworthy that in the entire rocky area of the Tvärminneön peninsula, its neighbourhood and islands of the Tvärminne archipelago (including forests) there are virtually no empty mounds of species of the subgenera Formica s. str. and Coptoformica Müll. As soon as a colony abandons a nest or dies out, the nest is invaded by a colony of another species, usually $F$. fusca; sometimes the invasion takes place already during the removal or dying-out process (Czechowski \& Vepsäläinen 1999a, b, Czechowski 2002 and unpublished observations). These findings complete our description of the nesting situation of the local ants.

Cases of (temporary) plesiobiosis between $F$. fusca and (declining) colonies of wood ants are of special interest, as the former is usually not able to nest close to mature colonies of the latter, or at least nesting within their territory, is subject to some restrictions (Vepsäläinen \& Pisarski 1982, Savolainen 1990, 1991). On the other hand, it should be pointed out that $F$. fusca and wood ants are partners in temporary social parasitism (the former as the host, the latter as the parasite). Therefore, the possibility of plesiobiotic co-existence of pairs of such species may shed light on the evolution of social parasitism in ants, as it fits within the concept of evolution beginning with plesiobiosis (Wilson 1971).

Acknowledgements. The field investigations in Finland were made at the Tvärminne Zoological Station of the University of Helsinki within the programme of scientific cooperation between the Polish Academy of Sciences and the Academy of Finland. The author thanks Kari Vepsäläinen and an anonymous referee for their helpful comments on the manuscript.

\section{References}

Czechowski, W. 1985: Competition between Myrmica laevinodis Nyl. and Lasius niger (L.) (Hymenoptera, Formicoidea). - Annales Zoologici 39: 153-173.

Czechowski, W. 1999: Lasius fuliginosus (Latr.) on a sandy dune - its living conditions and interference during raids of Formica sanguinea Latr. (Hymenoptera, Formicidae). - Annales Zoologici 49: 117-123.

Czechowski, W. 2000: Interference of territorial ant species in the course of raids of Formica sanguinea Latr. (Hymenoptera, Formicidae). - Annales Zoologici 50: 35-38.
Czechowski, W. 2001: Mixed colony of Formica pratensis Retz. + Formica cinerea Mayr + Formica sanguinea Latr. (Hymenoptera, Formicidae) and its presumed origin. - Annales Zoologici 51: 205-209.

Czechowski, W. 2002: Plesiobiosis between Formica fusca L. and wood ants (Hymenoptera, Formicidae) as a sign of nest competition. - Przegląd Zoologiczny 46: 8186. [In Polish].

Czechowski, W. 2003: Plesiobiosis between Formica fusca L. and Myrmica rubra (L.) (Hymenoptera, Formicidae). - Przegląd Zoologiczny 47: 115-118. [In Polish].

Czechowski, W. \& Czechowska, W. 2000: Formica cinerea fuscocinerea For. in the Pieniny Mts - its untypical habitat and plesiobiosis with Lasius flavus (F.) (Hymenoptera, Formicidae). - Fragmenta Faunistica 43: 131-133.

Czechowski, W. \& Rotkiewicz, W. 1997: Common activities of female sexuals of Lasius umbratus (Nyl.) and Formica sanguinea Latr. or Polyergus rufescens (Latr.) on nests of the dulotic species (Hymenoptera, Formicidae). - Annales Zoologici 47: 465-467.

Czechowski, W. \& Vepsäläinen, K. 1999a: Plesiobiosis between Formica fusca L. and Formica aquilonia Yarr. (Hymenoptera, Formicidae). - Annales Zoologici 49: 125-127.

Czechowski, W. \& Vepsäläinen, K. 1999b: Plesiobiosis between Formica fusca L. and wood ants (Hymenoptera, Formicidae). - Przegląd Zoologiczny 43: 215-218. [In Polish].

Czechowski, W. \& Vepsäläinen, K. 2001: Formica rufa L. indirectly protects $F$. fusca L. against $F$. sanguinea Latr. raids (Hymenoptera, Formicidae). - Annales Zoologici 51: 113-119.

Czechowski, W. \& Yamauchi, K. 1998: Plesiobiosis of Formica japonica Motsch. and Tetramorium sp. (Hymenoptera: Formicidae). - Annals of the Upper Silesian Museum 8/9: 99-101.

Gallé, L. 1991: Structure and succession of ant assemblages in north European sand dune area. - Holarctic Ecology 14: $31-37$.

Hölldobler, B. \& Wilson, E. O. 1990: The ants. — SpringerVerlag, Berlin. xii +732 pp.

Pisarski, B. \& Vepsäläinen, K. 1989: Competitive hierarchy in ant communities (Hymenoptera, Formicidae). Annales Zoologici 42: 321-329.

Savolainen, R. 1990: Colony success of the submissive ant Formica fusca within territories of the dominant Formica polyctena. - Ecological Entomology 15: 79-85.

Savolainen, R. 1991: Interference by wood ant influences size selection and retrieval rate of prey by Formica fusca. - Behavioral Ecology and Sociobiology. 28: 17.

Savolainen, R. \& Vepsäläinen, K. 1988: A competition hierarchy among boreal ants: impact on resource partitioning and community structure. - Oikos 51: 135-155.

Savolainen, R. \& Vepsäläinen, K. 1989: Niche differentiation of ant species within territories of wood ant Formica polyctena. - Oikos 56: 3-16.

Vepsäläinen, K. \& Pisarski, B. 1982: Assembly of island ant 
communities. - Annales Zoologici Fennici 19: 327335 .

Wasmann, E. 1891: Die zusammengesetzen Nester und gemischten Kolonien der Ameisen. - Aschendorffschen Buchdruckerei, Münster. vii + 262 pp.

Wheeler, M. W. 1901: The compound and mixed nests of American ants. - American Naturalist 35: 1007-1016.

Wheeler, M. W. 1926: Ants, their structure, development and behaviour. - Bulletin of the American Museum of Natural History 20: 347-375.

Wilson, E. O. 1971: The insect societies. - Belknap Press of Harvard University Press, Cambridge, Mass. $\mathrm{x}+548$ pp.

Wuorenrinne, H. 1958. Muurahaisten lajienvälisistä suhteista. - Annales Zoologici Fennici 24: 19-28. 